\title{
Some Observations on Relationships of the Liver, Ovary and Body Weights for Pipefish Species at the Lake Bafa Coasts (Muğla)
}

\author{
Sule Gurkan $^{1 a^{*}}$, Ertan Taskavak $^{1 \mathrm{~b}}$, Deniz Innal ${ }^{2 \mathrm{c}}$ \\ ${ }^{I}$ Department of Hydrobiology, Faculty of Fisheries, Ege University, 35040 Bornova/Izzmir, Turkey \\ ${ }^{2}$ Department of Biology, Faculty of Science, Mehmet Akif Ersoy University, 15030 Burdur, Turkey
}

*Corresponding author

\begin{tabular}{l|l}
\hline A R T I C L E I N F O & A B S T R A C T \\
\hline Research Article & $\begin{array}{l}\text { This study aims to determine various relationships between liver, gonad and body weights of the } \\
\text { two pipefish species caught in two breeding seasons from the Bafa Lake (Mugla) coasts between } \\
2014-2016 . \text { Using beach seine-net in the lake, a total of } 208 \text { pipefish specimens (79 Synathus } \\
\text { abaster and } 129 \text { Synathus acus) were sampled. L-W relationship and Fulton condition factor were } \\
\text { W }=2 \mathrm{E}-0.9^{4.01}, 0.035 \pm 0.009 \text { in S.abaster } \text { specimens. Also LW relationships and condition factor } \\
\text { were W }=8 \mathrm{E}-0.9^{3.83}, 0.033 \pm 0.01 \text { in } S \text {. acus. On the other hand mean } \pm \text { SD of HSI and GSI values } \\
\text { were } 2.18 \pm 1.65 \text { and } 7.69 \pm 7.12 \text { respectively. In S.acus values } 3.22 \pm 3.13 \text { and } 5.49 \pm 5.12 \text { as } \\
\text { well. The decrease in HIS and K values, provides sufficient information to claim that species in } \\
\text { the lake spend all energy requirement obtained with proper feeding to growth and gonad } \\
\text { development. }\end{array}$ \\
$\begin{array}{l}\text { Accepted : } 15 / 01 / 2019 \\
\text { Keywords: }\end{array}$ &
\end{tabular}

\section{Pipefish}

Syngnathus abaster

Syngnathus acus

Hepatosomatic index

Lake Bafa

Turkey

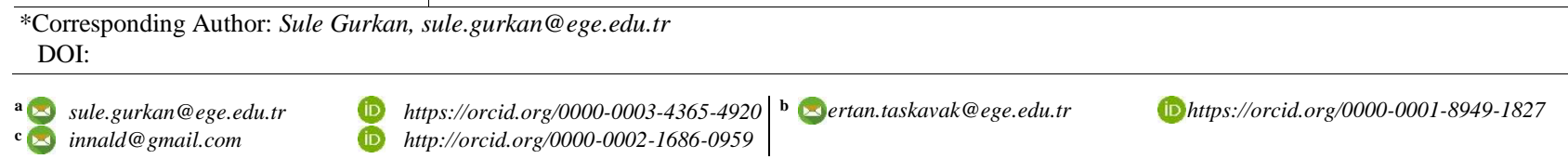

(c) $\underset{\mathrm{EY}}{(\text { ) }(9)}$ This work is licensed under Creative Commons Attribution 4.0 International License

\section{Introduction}

Syngnathus abaster and Syngnathus acus (Fam: Syngnathidae) are distributed along eastern Atlantic coasts and also Mediterranean and Black sea (Dawson, 1986). These species are abundant in sea, brackish waters and fresh waters (Movčan, 1988). Although they have not economic importance, have attracted attention due to their reversed sex roles (Berglund et al., 1986) and few reproductive seasons (Franzoi et al., 1993; Campbell and Able, 1998) to different researchers from the world.

The condition factor, defined as good nutrition index, shows changes in the amount of stored nutrients in the fish muscle. The condition factor, which reveal a feeding activity of a species, is used to determine whether they utilize the nutritional sources in best way. Fish condition is affected by gonad weight and body weight of fish (Mahboob and Sheri, 2002). In bony fish, gonad weight depends, in part, on body weight (Mahboob and Sheri, 1997). According to Mahboob and Sheri (2002), gonadosomatic index (GSI) is defined as the ratio of gonadal development to gonadal activity. Gonadal regeneration in female fish contains protein deposition and lipid absorption of developing oocytes and the source of these depositions can be the liver in many species depending on oocyte development (Mahboob et al., 2002). Hepatosomatic Index (HSI) is defined as the ratio of liver weight to total body weight and used as a measure of the energy reserves of an animal, especially in fish. The relationship between liver weight and body weight is given by seasonal variation (Mahboob et al., 2002). Analyses of $\mathrm{CF}, \mathrm{HSI}$ and GSI of fish species may reveal information on the general health condition of the organisms.

Hepatosomatic Index (HSI), Fulton condition factor (CF) and gonadosomatic index (GSI) knowledges of $S$. abaster and S.acus are virtually undocumented from lake environmental. The aim of this study is to determine the relationships of gonad, liver and body weights between the two pipefish species from the lake environment in Turkey. 


\section{Material and Method}

Using beach seine-net at the lake coasts, a total of 208 pipefish specimens (79 S.abaster and 129 S.acus) were sampled during the fall and spring seasons between the years of 2014 and 2016 .The specimens caught were transported to the laboratory in plastic containers containing $70 \%$ alcohol. TL of the specimens were measured in centimeters using a measuring board and the each fish was weighted (W) with a digital scale.

Length -weight relationship was determined for the samples according to the formula $\mathrm{W}=\mathrm{aL}^{\mathrm{b}}$. For the changes of gonadosomatic index (GSI), the equation,

$$
\mathrm{GSI}=\left[\mathrm{W}_{\mathrm{g}} \times\left(\mathrm{W}-\mathrm{W}_{\mathrm{g}}\right)^{-1}\right] \times 100(\text { Ricker 1975) }
$$

was used and Fulton condition factor was calculated according to the formula,

$$
\mathrm{K}=\mathrm{W} / \mathrm{L}^{3} \times 100
$$

Analysis of variance (ANOVA) and t-test were performed with the STATISTICA package program.

\section{Results and Discussion}

The results obtained for $S$. abaster specimens are as follows; $\mathrm{W}=2 \mathrm{E}-09 \mathrm{~L}^{4.1}\left(\mathrm{R}^{2}=0.86\right)$ For S.acus; $\mathrm{W}=8 \mathrm{E}-$ 09L $\mathrm{L}^{3.83}\left(\mathrm{R}^{2}=0.83\right)$. According to $\mathrm{L}-\mathrm{W}$ relationship results found in this study, the two pipefish species have an allometric growth. (Figure 1a and b). The values of b in $S$. abaster and S.acus are compared with other studies.

According to these comparisons, $b$ value of $S$. abaster in this study is found to be higher than $b$ values obtained from other studies (Gurkan and Innal, 2018; Cakić et al., 2002; Khrystenko et al., 2015; Taylan et al., 2018) and similarly b value S.acus is lower than those given by Gurkan Taşkavak (2007) and Yildiz (2015).

Average condition value was calculated as $0.035 \pm$ 0.009 for S. abaster specimens. This result is consistent with the study conducted in the Danube river (Cakic et al., 2002). On the other hand, it is seen that this value obtained here is lower than this given for Aegean Sea (Taylan et al.,2018).

In $S$. abaster, the mean HSI was $2.18 \pm 1.65$ while mean GSI value was $7.60 \pm 7.12$, the (Figure $2 \mathrm{a}$ and $\mathrm{b}$ ).

Our results of GSI are higher than those given by Taylan et al. (2018).

In $S$. acus, the mean values of GSI, HSI and K were calculated as $5.49 \pm 5.12,3.22 \pm 3.13$ and $0.032 \pm 0.01$, respectively. (Figure $3 \mathrm{a}$ and $3 \mathrm{~b}$ )

Our GSI results are higher than those computed by Gurkan et al. (2009). On the other hand, the condition factor values are lower than those of Gurkan and Taskavak (2011). It is reported that the relationship between liver weight and body weight changes seasonally (Mahboob et al., 2002). According to this, it is understood that the HSI and GSI values were low due to the reproductive period of the $S$. acus in the region. According to those computed here for the $\mathrm{K}$ and HSI values, it was determined that there was statistical difference between two species (t-test p:0.010 $\mathrm{P}<0.05)$. On the other hand, it is seen that the K and HSI values, which are inversely correlated to allometric growth, show a decrease for both species.

Consequently, this decrease in HIS and $\mathrm{K}$ values provides sufficient information to claim that species in the lake spend all energy requirement obtained with proper feeding to growth and gonad development.

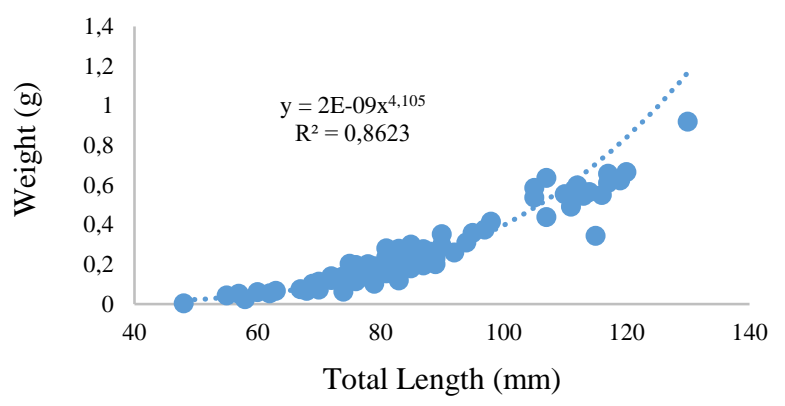

Figure 1a LW relationships in S.abaster

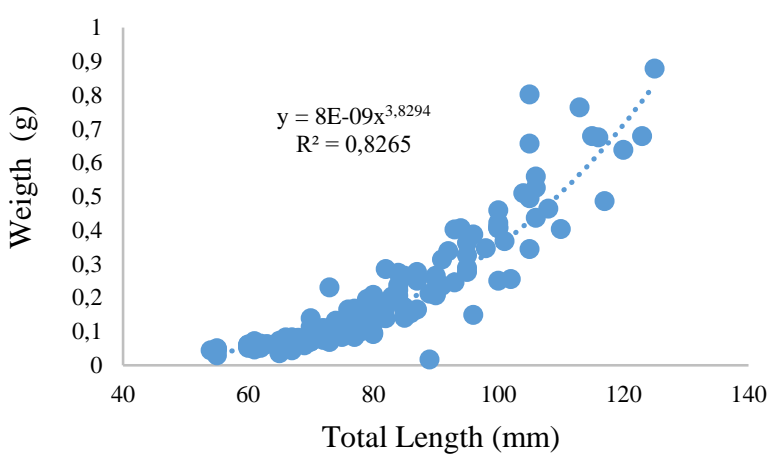

Figure 1b LW relationships in S.acus

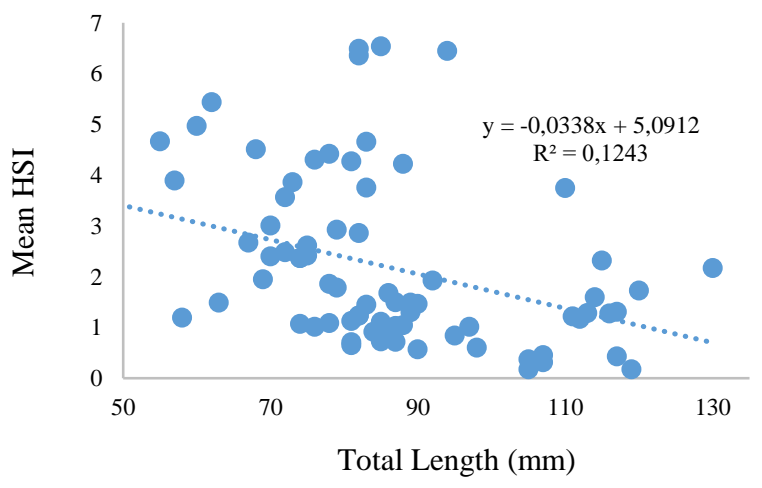

Figure 2a HSI and Length relaionships in S.abaster

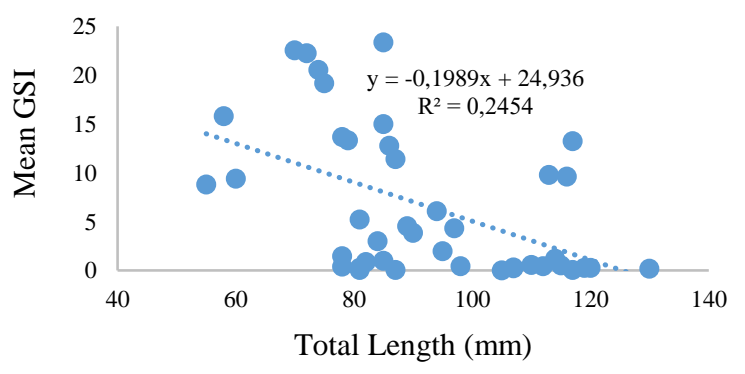

Figure 2b GSI and Length relaionships in S.abaster 


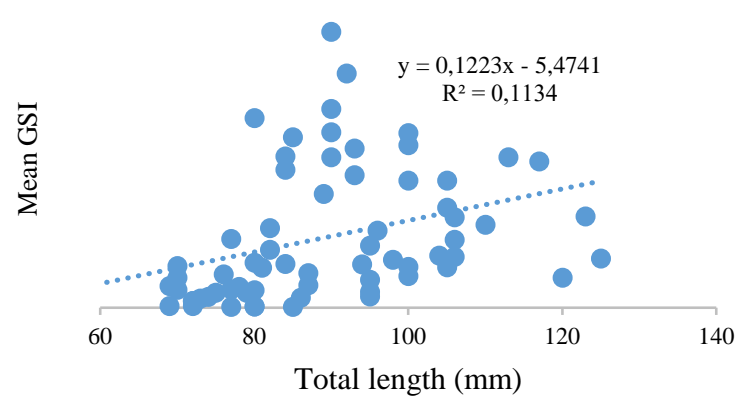

Figure 3a GSI-Total length relationships in S.acus

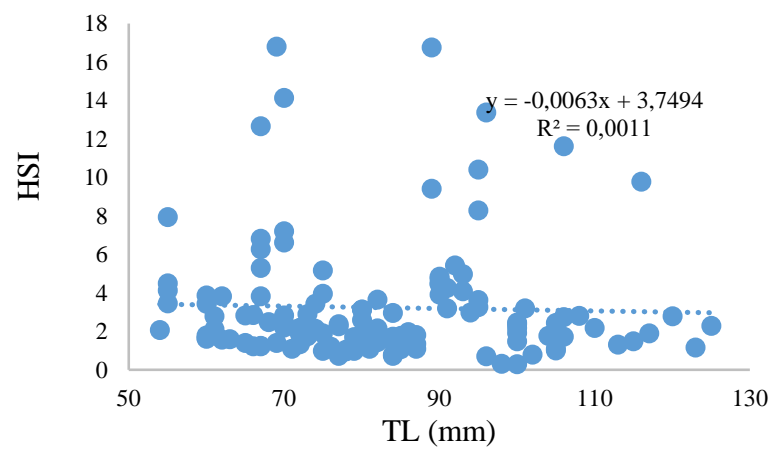

Figure 3b. HSI - Total length realionships in S.acus

\section{References}

Cakić P, Lenhardt M, Mićković D, Sekulić N, Budakov LJ. 2002. Biometric analysis of Syngnathus abaster populations. Journal of Fish Biology, 60: 1562-1569.

Campbell BC, Able KW. 1998. Life history characteristics of the northern pipefish, Syngnathus fuscus in southern New Jersey. Estuaries, 21: 470-475

Dawson, CE 1986. Syngnathidae. p. 445-458. In M.M. Smith and P.C. Heemstra (eds.) Smiths' sea fishes. Springer-Verlag, Berlin

Franzoi P, Maccagnani R. Rossi R. Ceccherelli VU. 1993. Life cycles and feeding habits of Syngnathus taenionotus and $S$. abaster (Pisces, Syngnathidae) in a brackish bay of the Po River Delta (Adriatic Sea). Marine Ecology Progress Series, 97: 78-81.
Gurkan S, Taskavak E. 2007. Length-weigth relationships for syngnathid fishes of the Aegean Sea, Turkey, Belgian Journal of Zoology, 137(2): 219-222.

Gurkan S, Taskavak E, Hossucu, B. 2009. The reproductive biology of the Great Pipefish Syngnathus acus (Family: Syngnathidae) in the Aegean Sea North-Western Journal of Zoology, 5(1): 179-190.

Gurkan, S, Taşkavak E. 2011. Seasonal Condition Factors of Syngnathid Species Caugth from Aegean Sea Coasts. Ege Journal of Fisheries and Aquatic Sciences, 28(1): 21-24.

Gurkan S, Innal D. 2018. Some morphometric features of congeneric pipefish species (Syngnathus abaster Risso 1826, Syngnathus acus Linnaeus, 1758) distributed in Lake Bafa (Turkey). Oceanological and Hydrobiological Studies, 47(3): 239-247.

Khrystenko D, Kotovska G, Novitskij R. 2015. Length-Weight Relationships and Morphological Variability of Black Striped Pipefish Syngnathus abaster Risso, 1827 in the Dnieper River Basin. Turkish Journal of Fisheries and Aquatic Sciences.15: 609-618.

Mahboob S, Sheri AN. 1997. Relationships among ovary weight, liver weight and body weight in female graa carp C. idella. Journal of Aquaculture in The Tropics, 12: 255-259.

Mahboob S, Sheri AN. 2002. Relationships among ovary weight, liver weight and body weight of Major, common and some Chinese carps under composite culture system with special reference to pond fertilization. Asian-Australasian Journal of Animal Sciences, 15(5): 740-744.

Movčan YV. 1988. Fauna Ukrainy (Ryby). [Fauna of Ukraine (Fishes)]. Kiev: Naukova Dumka (in Russian).

Ricker WE. 1975. Computation and interpretation of biological statistics of fish populations. Bulletin of the Fisheries Research Board of Canada, Bulletin 191.

Taylan B, Tatarhan GE, Aksoy O, Culha M. 2018. Reproductive biology of the black-stripedpipefish Syngnathus abaster Risso,1827 (Pisces: Syngnathidae) in the Aegean Sea of Turkey. Oceanological and Hydrobiological Studies 47 (1): 67-74

Yildiz T. Uzer U, Karakulak FS. 2015. Preliminary report of a biometric analysis of greater pipefish Syngnathus acus Linnaeus, 1758 for the western Black Sea. Turkish Journal of Zoology, 39: 917-924. 